\title{
Middle Jurassic sandstone deposition in the Wandel Sea Basin: evidence from cardioceratid and kosmoceratid ammonites in the Mågensfjeld Formation in Kilen, North Greenland
}

\author{
Peter Alsen ${ }^{\star 1} \oplus$, Jussi Hovikoski ${ }^{1}$, Kristian Svennevig ${ }^{\circledR}$ \\ ${ }^{1}$ Geological Survey of Denmark and Greenland (GEUS), Copenhagen, Denmark
}

\begin{abstract}
Age assessments from both palynostratigraphy and macrofossil biostratigraphy of the sandstone-dominated Mågensfjeld Formation, Wandel Sea Basin, North Greenland were hitherto hampered by post-burial thermal degradation of dinoflagellate cysts and a lack of well-preserved macrofossils. The formation was previously assigned to the Upper Cretaceous based on erroneous fossil identifications. Finds of cardioceratid and kosmoceratid ammonites during recent field work now provide the first age control of the unit, demonstrating it to be of late Bajocian - late Bathonian and perhaps Callovian (Middle Jurassic) age. This makes it among the oldest Jurassic units, perhaps even Mesozoic units, recorded in Kilen, North Greenland and eastern North Greenland. Previously, the complex structural and tectonic evolution of the area was poorly understood, and the structural relation of the Mågensfjeld Formation to the surrounding Mesozoic units was a puzzle. The new age assessment simplifies the structural situation in the area significantly. Further, the inference of a large reverse fault previously required to explain the proximity of the Mågensfjeld Formation to neighbouring Jurassic units is now unnecessary. The data show that the Wandel Sea Basin was influenced by the Middle Jurassic transgression and had sufficient accommodation space for marine deposition earlier than previously thought. The unit serves as a key datapoint and analogue for possible Middle Jurassic units in adjacent offshore basins.
\end{abstract}

\section{Introduction}

The first ever fossils reported from Kilen in eastern North Greenland (Fig. 1) were collected by the Greenarctic Consortium and included the ammonite Cranocephalites vulgaris, Spath and various bivalves (Dawes 1976; Dawes \& Peel 1981). The fossils indicated the presence of a Middle Jurassic succession, but their exact location was not known. At this time, the geology of Kilen had been interpreted solely from aerial photos as Proterozoic-Palaeozoic strata deformed during the Caledonian orogeny (Haller 1970). Hence, the discovery of Mesozoic fossils prompted the need for further field observations in this remote and inaccessible area. During pioneering expeditions in 1980, 1985 and 1998, E. Håkansson and co-workers collected lithological,

\author{
*Correspondence: pal@geus.dk \\ Received: 26 June 2020 \\ Accepted: 17 Sept 2020 \\ Published: 21 Dec 2020
}

Keywords: ammonite stratigraphy, Middle Jurassic, North Greenland, sandstone deposition, Wandel Sea Basin

\section{Abbreviations: \\ NHMD: Natural History Museum of Denmark \\ MGUH: Museum Geologica Universitas Hafniensis/Geological Museum type collection (Copenhagen, Denmark) FA: facies association}

GEUS Bulletin is an open access, peerreviewed journal published by the Geological Survey of Denmark and Greenland (GEUS). This article is distributed under a CC-BY 4.0 licence, permitting free redistribution, and reproduction for any purpose, even commercial, provided proper citation of the original work. Author(s) retain copyright.

Edited by: Sofie Lindström (GEUS, Denmark)

Reviewed by: Mikhail Rogov (Geological Institute of RAS, Russia) and one anonymous reviewer.

Funding: See page 15

Author contributions: See page 16

Competing interests: See page 16

Additional files: None provided 


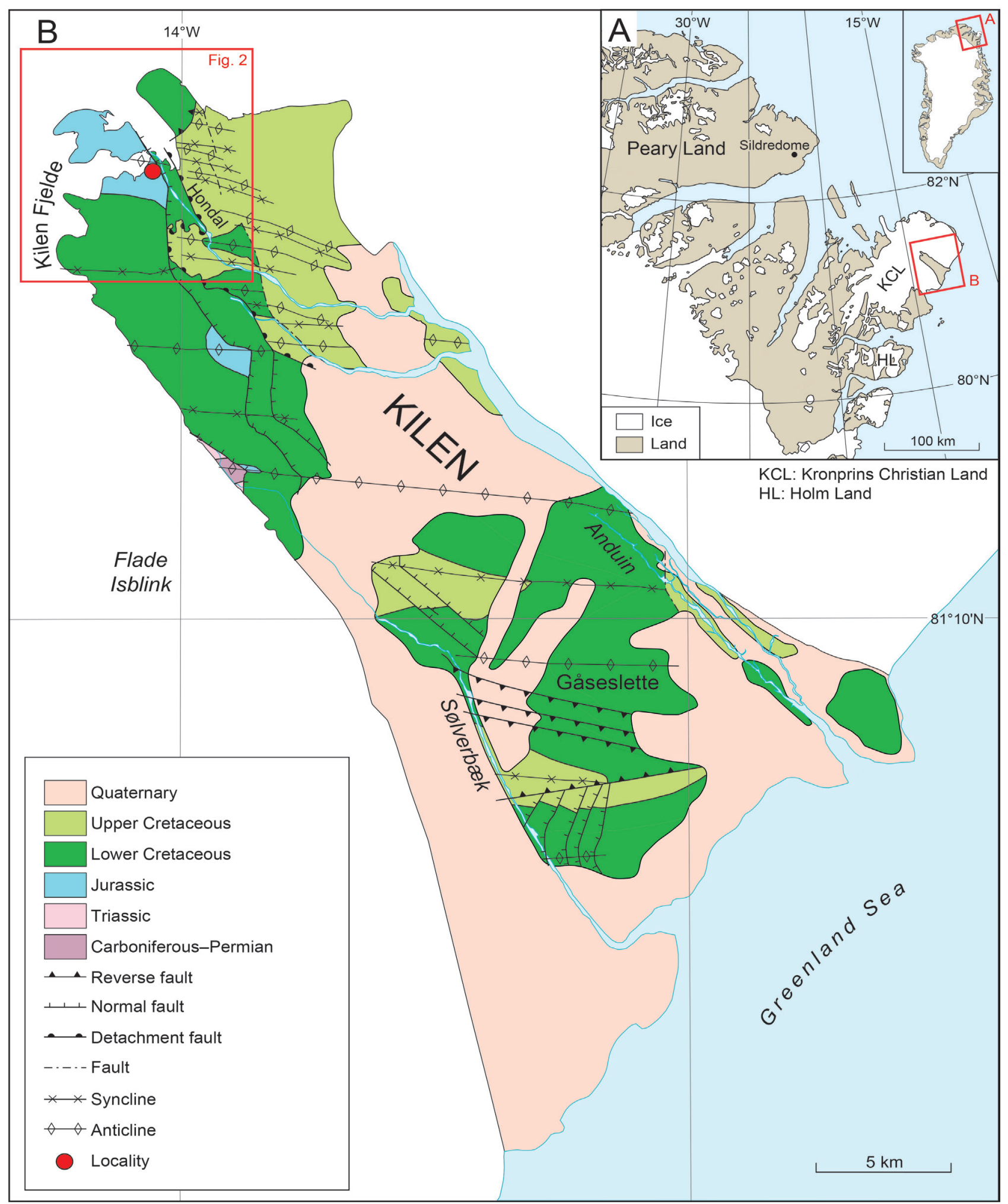

Fig. 1 Simplified geological map of Kilen in the Wandel Sea Basin. A: The Wandel Sea Basin is a post-Caledonian fault-bounded Carboniferous-Lower Palaeogene sedimentary basin in eastern North Greenland (Dawes \& Soper 1973; Håkansson \& Stemmerik 1989; Stemmerik et al. 1998). It covers the geographical areas of Holm Land (HL), Kronprins Christian Land (KCL) and eastern Peary Land. B: The location of the Mågensfjeld Formation outcrop locality and the area covered by Fig. 2 are shown. Modified from Svennevig et al. (2016).

sedimentological and biostratigraphic data in Kilen. They described an essentially Upper Jurassic - Upper Cretaceous succession (Håkansson et al. 1981b, 1991, 1993; Pedersen 1991; Dypvik et al. 2002), whereas the
"Middle Jurassic" ammonites reported by Dawes (1976) were identified as mid-Cretaceous (Albian) Anahoplites cf. daviesi ornata, Spath and a gastroplitinid (Birkelund \& Håkansson 1983). 

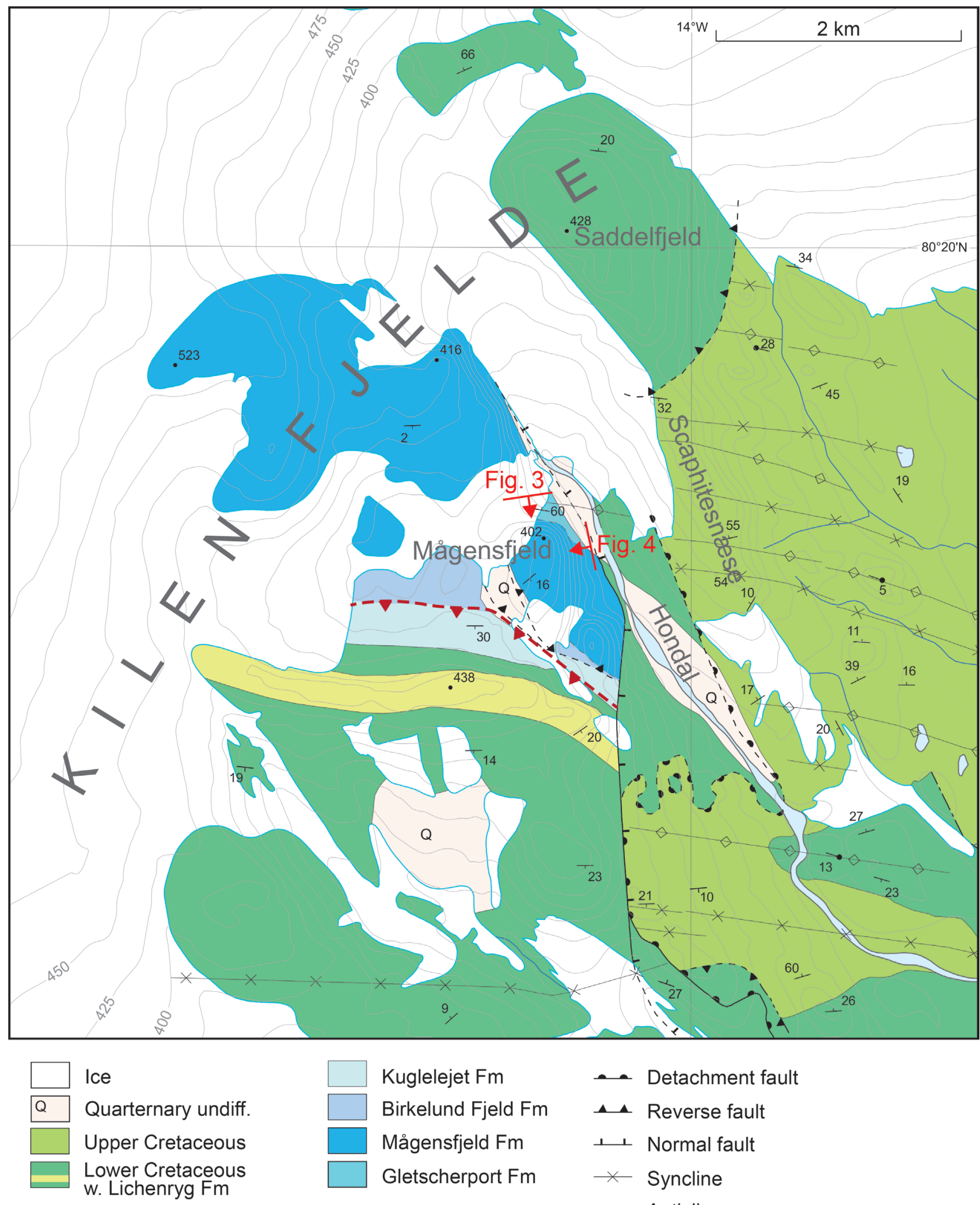

Kuglelejet Fm

Birkelund Fjeld Fm

Mågensfjeld $\mathrm{Fm}$

Gletscherport Fm

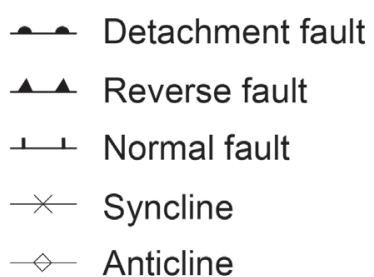

- $\boldsymbol{\nabla}$ - Fault suggested by Pedersen

Fig. 2 Detailed geological map of northern Kilen Fjelde. The geological situation around the Mågensfjeld Formation outcrop and the position of Figs 3 and 4 are shown. The latter indicates the location of the Mågensfjeld type section, which was logged, and where ammonites were collected. The now redundant reverse fault suggested by Pedersen (1991) and Håkansson et al. (1993) is indicated by a red dashed line. Modified from Svennevig (2018). 
During a recent field campaign in North Greenland, new data were retrieved from Kilen. This area is key for studying the Jurassic-Cretaceous of North Greenland and its relation to the conjugate Barents Margin, both lithologically and structurally. In 2012 and 2013, field teams sampled and logged all the sedimentary units described by Håkansson et al. (1981, 1991, 1993). The objective of the recent campaign was to refine the biostratigraphy and establish a formal lithostratigraphic framework for an improved understanding of the depositional evolution of the succession (Bojesen-Koefoed et al. 2014; Svennevig et al. 2016; Alsen et al. 2017; Hovikoski et al. 2018). Several Cretaceous intervals and units were poorly dated or not dated at all. The succession has been subject to significant thermal influence, which has removed organic palynomorphs hampering the use of dinoflagellate cysts stratigraphy (Håkansson \& Pedersen 2001; Svennevig et al. 2017; Pedersen et al. 2018). Macrofossils are absent or scarce and poorly preserved in several units. Only a few intervals and units have published biostratigraphic ages (Birkelund \& Håkansson 1983), whereas more detailed biostratigraphy were presented in unpublished reports (Håkansson 1994; Håkansson et al. 1994).

Parallel to the biostratigraphic and lithostratigraphic work, the structural geology of Kilen was revised based on mapping from oblique photogrammetry and field work (Svennevig et al. 2015). A new structural model for Kilen was published, in which it was shown that Late Cretaceous extension caused normal faulting followed by Eurekan compression, which gave rise to folding and thrusting (Svennevig et al. 2016, 2017, 2018).

A thick sandstone succession in northwesternmost Kilen Fjelde (the northern part of Kilen) is informally referred to as Unit 7 by Håkansson et al. (1993) and forms the best exposed sediment succession in Kilen. The steep, vertical outcrops in cliffs with nesting ivory gulls gave the unit its name: Mågensfjeld Formation (Fig. 2). In Danish, Mågensfjeld refers to "mountain of the seagull." Pioneer geologists working in the region used the name "Fuglefjeld" (Danish for bird cliff). The age of the unit was considered Coniacian (Late Cretaceous) due to the identification of inoceramid bivalves at the base of the section, and common imprints after belemnites and allegedly Late Cretaceous baculitid ammonites (Håkansson et al. 1994). A Late Cretaceous age of the Mågensfjeld Formation significantly added to the structural complexity of Kilen Fjelde, and a large reverse fault was introduced to explain its proximity to Upper Jurassic units (Pedersen 1991; Håkansson et al. 1993).

In this paper, we report new finds of fossils from Mågensfjeld in Kilen, collected in 2013, which demonstrate a Middle Jurassic age of the Mågensfjeld Formation. The dating of the unit has significant importance for the understanding of the structural geology of the area.

\section{Geological setting}

Kilen forms part of the Wandel Sea Basin in North Greenland. It is a fault-bound basin containing a Carboniferous - lower Palaeogene sedimentary succession (Dawes \& Soper 1973; Håkansson \& Stemmerik 1989; Stemmerik et al. 1998). The succession in Kilen is Triassic - Upper Cretaceous (Håkansson et al. 1993; Alsen et al. 2017; Hovikoski et al. 2018). The area was deformed by several structural events, namely latest Cretaceous extensional faulting followed by compression of presumably Paleocene age. It has been divided into two major thrust sheets, which contain numerous smaller fault-bound structural units (Svennevig et al. 2016, 2018). As a result, strata are folded and lithostratigraphic units are commonly fault bound (Svennevig et al. 2016; Hovikoski et al. 2018).

\section{Locality}

The Mågensfjeld Formation is exposed in the innermost, north-western part of the ice-bounded semi-nunatak Kilen, surrounded by the ice cap Flade Isblink. The type section is situated at the steep north-east-slope of Mågensfjeld in the uppermost reaches of the Hondal valley (Figs 1-4; Hovikoski et al. 2018; Svennevig 2018).

\section{Materials and methods}

\subsection{D mapping of Mågensfjeld}

The structural mapping of the Mågensfjeld area builds on the geological map of Kilen (Svennevig 2018), which was mapped mainly by oblique photogrammetry (Svennevig et al. 2015). Oblique photographs were taken by a handheld digital camera from a helicopter, and triangulated and georeferenced, so that visible geological features such as bedding and faults could be mapped as 3D polylines. The polylines were used to calculate strike and dip of bedding and faults. These parameters were imported into a 3D modelling software along with the 3D polylines, an unpublished digitised field map (Pedersen 1991), a digital

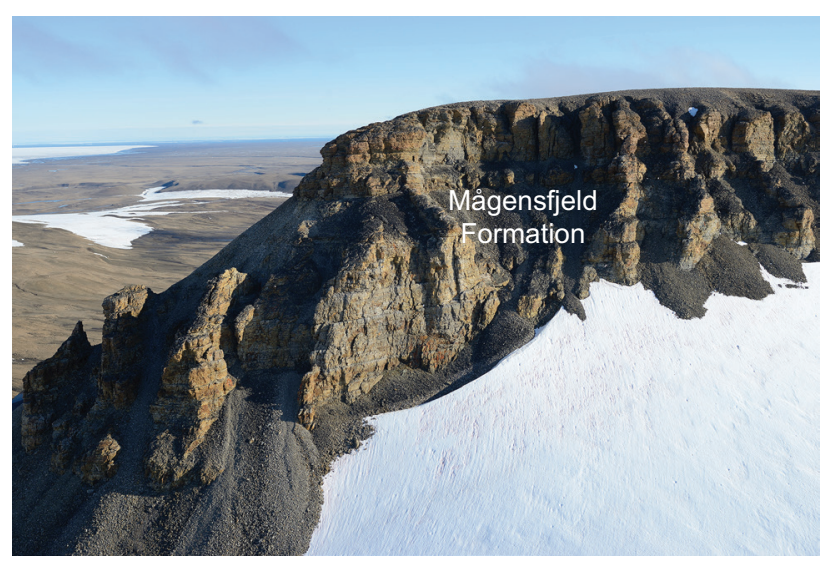

Fig. 3 View from helicopter of the Mågensfjeld Formation at the "bird cliff," Mågensfjeld, looking south. 


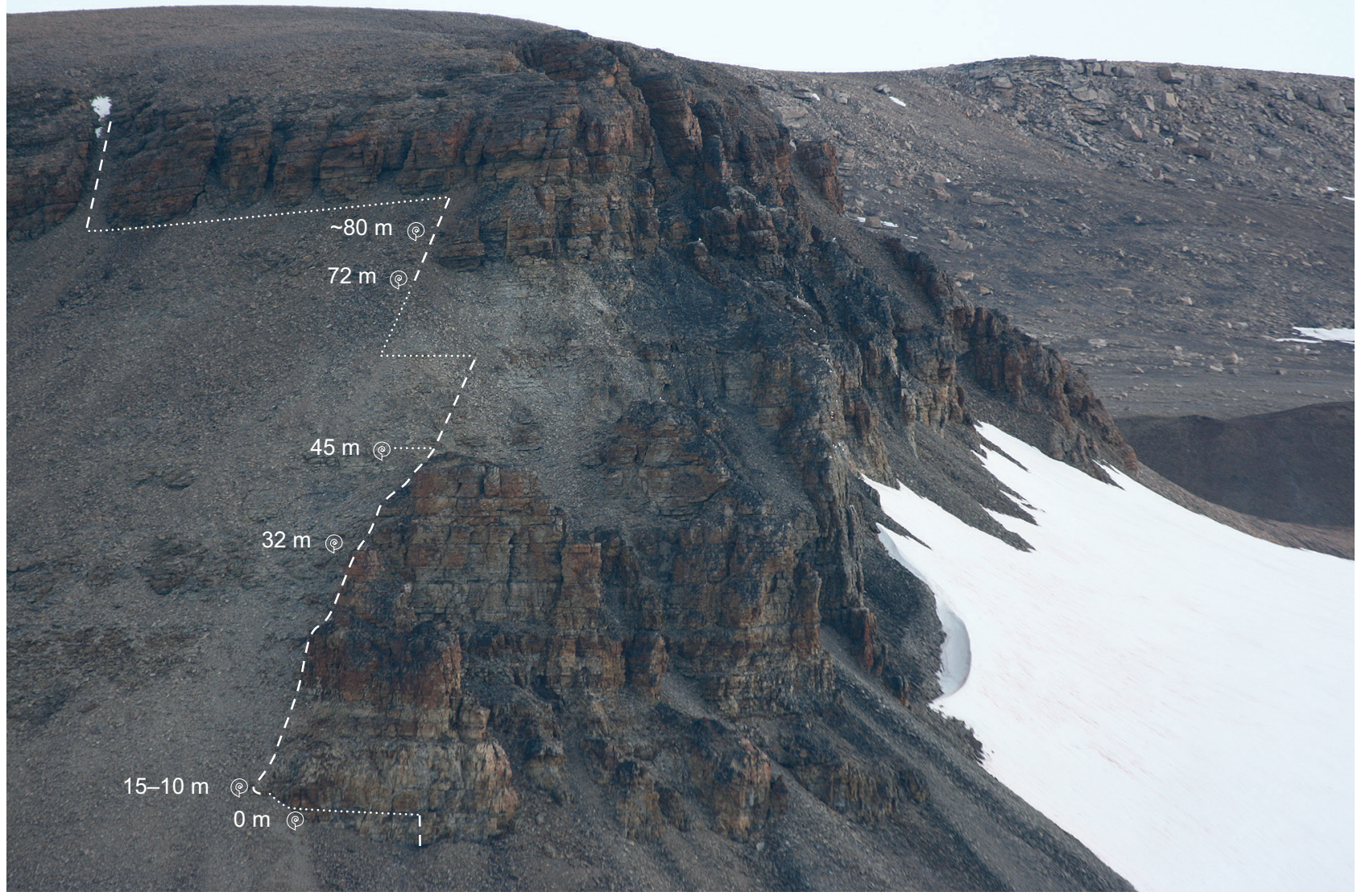

Fig. 4 View towards the west, showing the Mågensfjeld Formation type section at Mågensfjeld. This is perpendicular to the view shown in Fig. 3. Dashed line indicates the logged section (JHOV-5/2013). Ammonite-yielding levels are indicated.

elevation model and an orthophoto and georeferenced field observations. In the 3D modelling software, robust geological models (3D maps) were built and used for structural validation and to produce $2 \mathrm{D}$ maps and cross sections.

\subsection{Ammonites}

We were granted access to the ammonite collection established by the pioneer geologists working in the area. One sample from "Fuglefjeld" (now Mågensfjeld) was labelled "dissolved Baculites in sandstone" (the original label is in Danish), which is probably the reason for assigning the sample and the sandstone unit to the Upper Cretaceous (Coniacian). However, detailed inspection of the deeper part of the imprint of the dissolved supposed baculitid fossil shows the presence of a cone-shaped mould, which is clearly the filling of a belemnite alveolus. It adds to our own field observations that belemnites are common in the Mågensfjeld Formation, particularly in the lower part of the section. The report of Late Cretaceous inoceramids is also erroneous, as the inoceramid bivalves, which are relatively common, belong to the genus Retroceramus. Hence, there are no indications of Upper Cretaceous.
Our own collection contains 35 ammonite specimens collected in 2013 from the type section of the Mågensfjeld Formation. Some samples were found loose in the scree below the outcrop; other specimens were found in situ at various levels throughout the measured section (Figs 4 and 5). Most specimens are poorly preserved, broken and fragmented. The sandstone in which they are contained has undergone significant alteration through diagenesis with extensive quarts cementation. Fossils are commonly partly dissolved. The fossil material, however, contains readily identifiable specimens, which we have compared to the Jurassic ammonite reference collection curated by J.H. Callomon between 1960 and 2010 (Callomon 1961, 1985, 1993; Callomon et al. 2015). The reference collection is housed at the Geological Museum, Copenhagen, now part of the Natural History Museum of Denmark (NHMD). Specimens represent Middle Jurassic ammonites of the cardioceratid genera Cranocephalites, Arctocephalites, Arcticoceras, Cadoceras and of the kosmoceratid genus Kepplerites. Selected ammonite specimens from Mågensfjeld Formation in Kilen are shown in Figs 6 and 7.

\section{Palaeontology}

Our field work resulted in the discovery of numerous ammonites in situ in a number of levels throughout the 

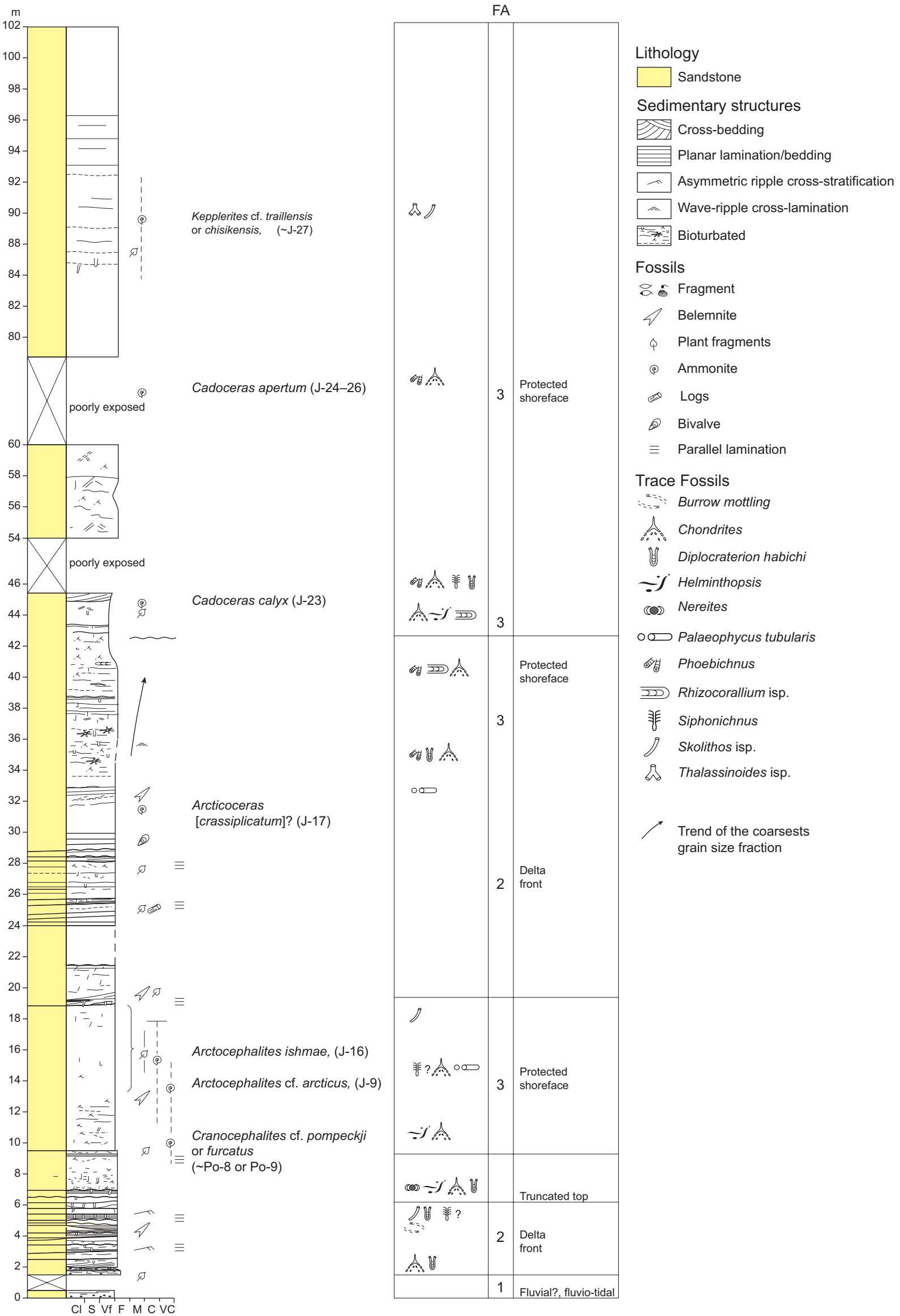

$\equiv$ Parallel lamination

Trace Fossils

$\therefore=\infty$ Burrow mottling

$\therefore$ Chondrites

[f Diplocraterion habichi

-j Helminthopsis

$\cos$ Nereites

○อ Palaeophycus tubularis

\% Phoebichnus

DDhizocorallium isp.

非 Siphonichnus

$\int$ Skolithos isp.

in Thalassinoides isp.

$\infty$

Trend of the coarsests
grain size fraction

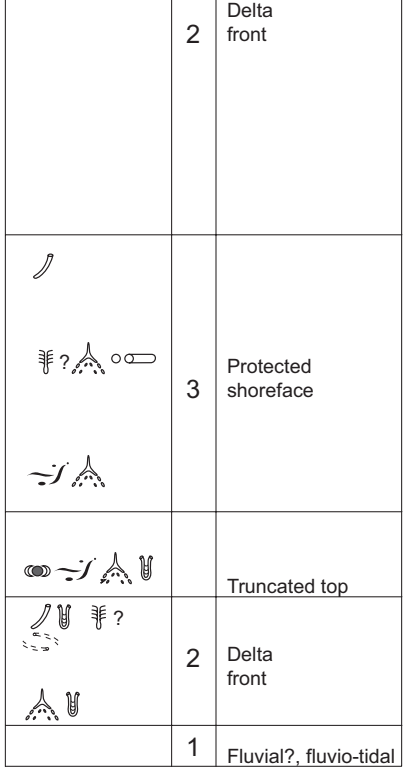

Fig. 5 Measured sedimentological log of the type section of the Mågensfjeld Formation (JHOV-5/2013). FA: facies association; Po-8, Po-9, J-9 to J-27: Faunal horizons for North-East Greenland (see Fig. 8); Po: Pompeckji; J: Jameson Land. Modified from Hovikoski et al. (2018, fig. 8B). 

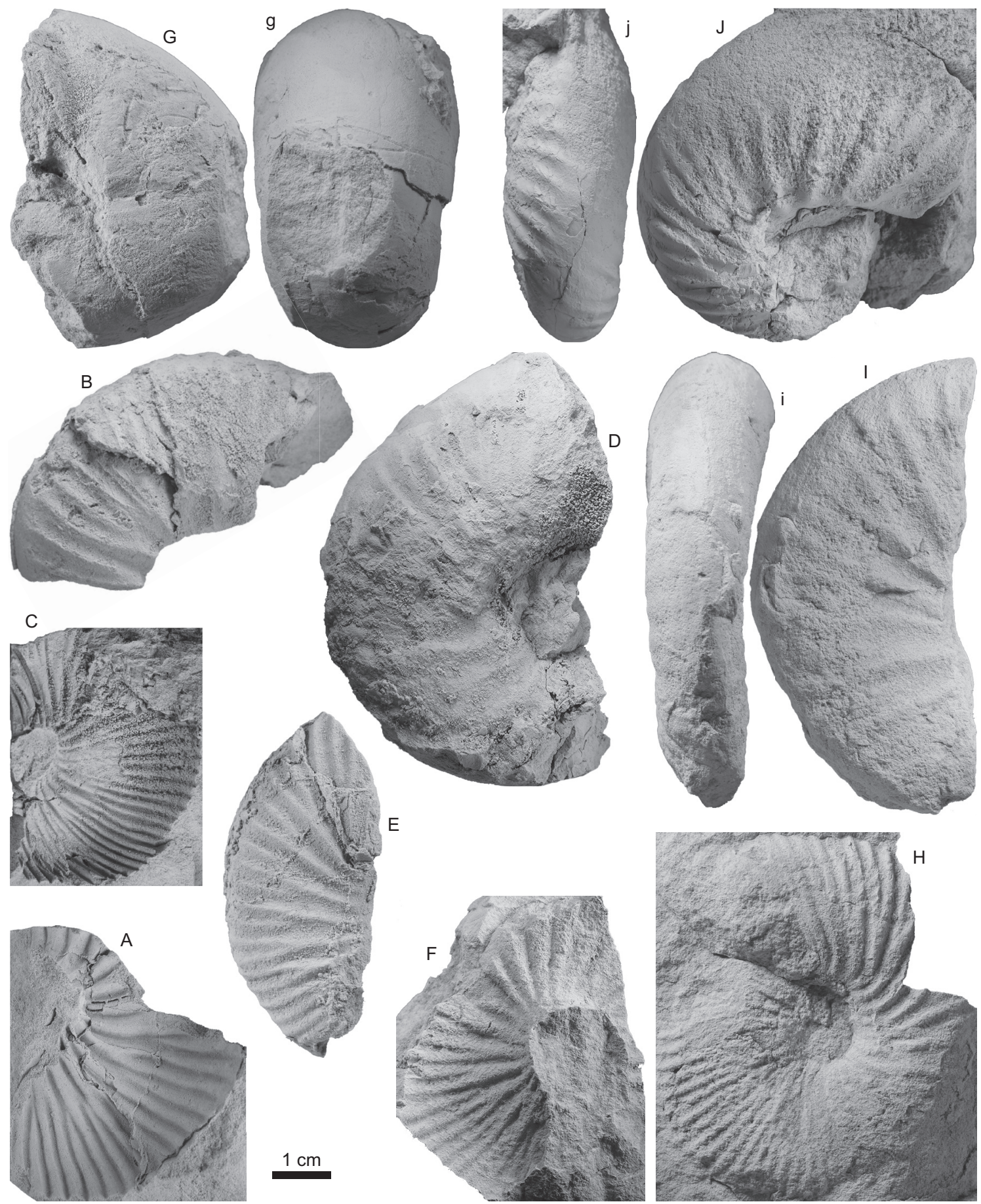

Fig. 6 Selected cardioceratid ammonites from the Mågensfjeld Formation. A-F: Cranocephalites sp. cf. pompeckji or furcatus MGUH 33462-33467 (all from GEUS 545584). G, g: Side and ventral views, respectively, of Arctocephalites sp. delicatus or arcticus MGUH 33468 (from GEUS 545586). H: Arcticoceras ishmae, MGUH 33469 (from GEUS 545569). I, i and J, j: Side and ventral views of two specimens of Arcticoceras spp. MGUH 33470 and 33471, respectively (from GEUS 545568).

c. 100-m thick measured section at Mågensfjeld (Fig. 5; chosen as the type section, see Hovikoski et al. 2018, Fig. 8B).

Figured specimens are assigned official numbers from the Geological Museum type collection (MGUH), Copenhagen, Denmark. These specimens are held in the NHMD repository. The remaining collections are housed at the Geological Survey of Denmark and Greenland (GEUS) and are assigned samples codes with the prefix "GEUS." In the following section, the following abbreviations apply: s.s: sensu stricto; MS: manuscriptum; spp. indet: species plurimae indeterminata; sp. aff.: species affinis; cf.: confer.

\subsection{Systematic taxonomy}

\section{Family Cardioceratidae Siemiradzki 1891}

Genus Cranocephalites Spath 1932

Cranocephalites cf. pompeckji (Madsen 1902) or C. furcatus Spath 1932

Figs $6 \mathrm{~A}-\mathrm{F}$ 


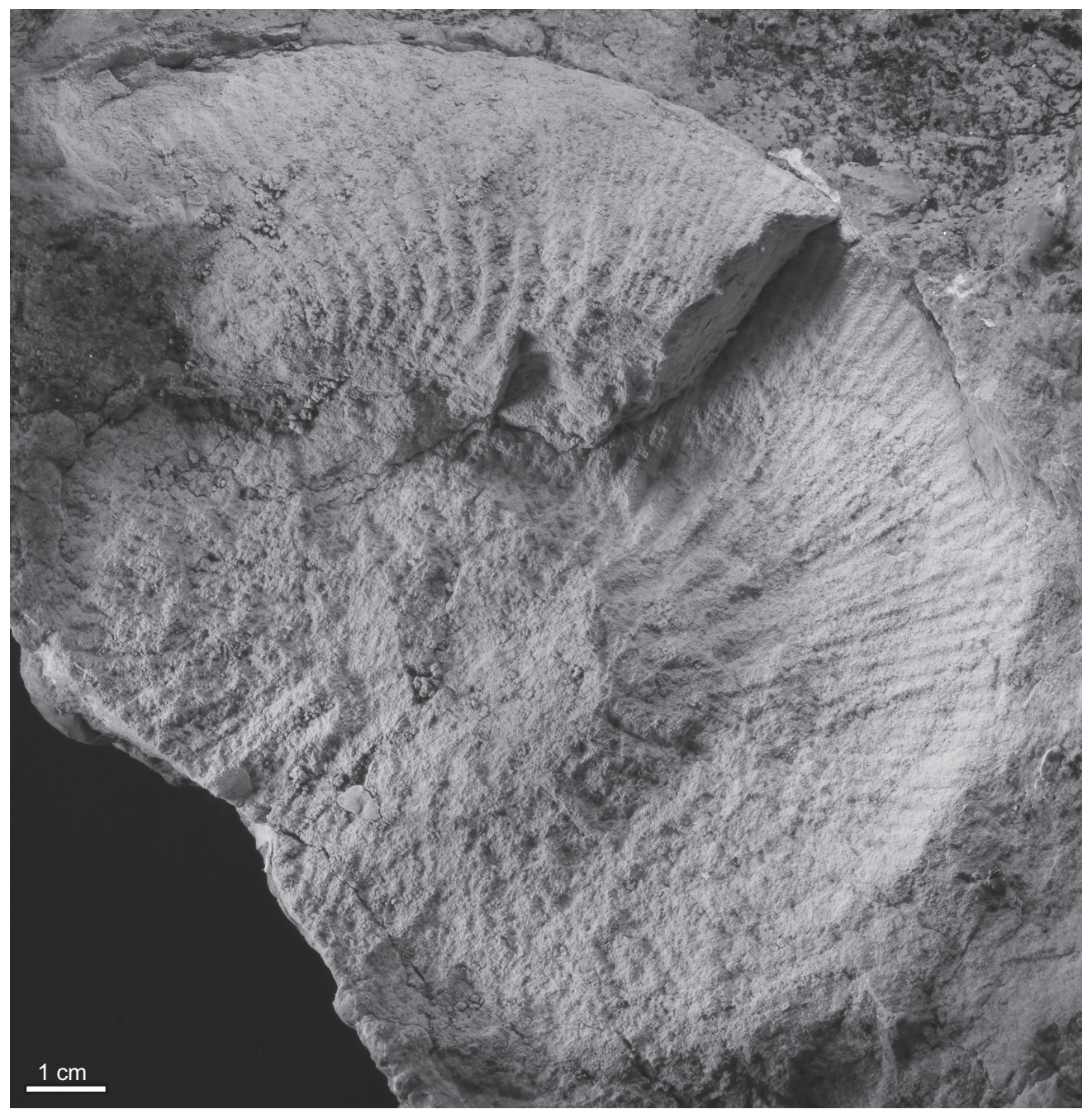

Fig. 7 Kepplerites cf. traillensis or chisikensis from Mågensfjeld Formation, MGUH 33472 (from GEUS 545591).

Material and horizon. 15 specimens (11 body fossil fragments, 4 imprints) illustrated specimens include MGUH 33462-33467 (from GEUS 545584) found laterally at c. $10 \mathrm{~m}$ height in the measured section (JHOV-5/2013; Figs 4 and 5).

Description. Assemblage of relatively involute to moderately involute forms. Ribbing fairly dense with strong primaries that divide into two or three secondaries at approximately mid flank. Occasional intercalatories. In late stages, ribbing becomes coarser and blunt and fades on the venter. Larger specimens tend to develop an inflated body chamber, typical of Cranocephalites. The reference to the group of C. pompeckji and furcatus rests on the tendency towards relatively flattened sides, and general resemblance of the size, ribbing and coiling compared with specimens in the reference collection.

Occurrence and stratigraphy. The group of C. pompeckji and furcatus is common fossils in central East and North-East Greenland, in particular on Jameson Land (Callomon 1993; Callomon et al. 2015) and on Traill $\varnothing$. The group represents the lower faunal horizons
Po-8 and Po-9 of the C. pompeckji Zone (Fig. 8; Donovan 1953, 1957; Alsen 2000; Vosgerau et al. 2004). C. pompeckji and furcatus are also reported in Siberia (Voronets 1962; Meledina 1973), Novaya Zemlya, northern Russia (Cherkesov \& Burdykina 1979) and Alaska (Imlay 1962).

Remarks. Specimens of C. pompeckji Zone ammonites were found loose (ex situ) in Kilen and on Peary Land (Nygaard 2003).

\section{Genus Arctocephalites Spath 1928 Arctocephalites cf. arcticus (Newton 1897)}

Figs $6 \mathrm{G}$ and $\mathrm{g}$

Material and horizon. One specimen, MGUH 33468 (from GEUS 545586), found loose in scree in the lower part of the section JHOV-5/2013 (Fig. 4).

Description. A medium-sized specimen with rounded inflated whorls. It is crushed and the umbilicus is not visible, but it is clearly an involute form and the umbilicus must have been minute. It resembles mature forms 


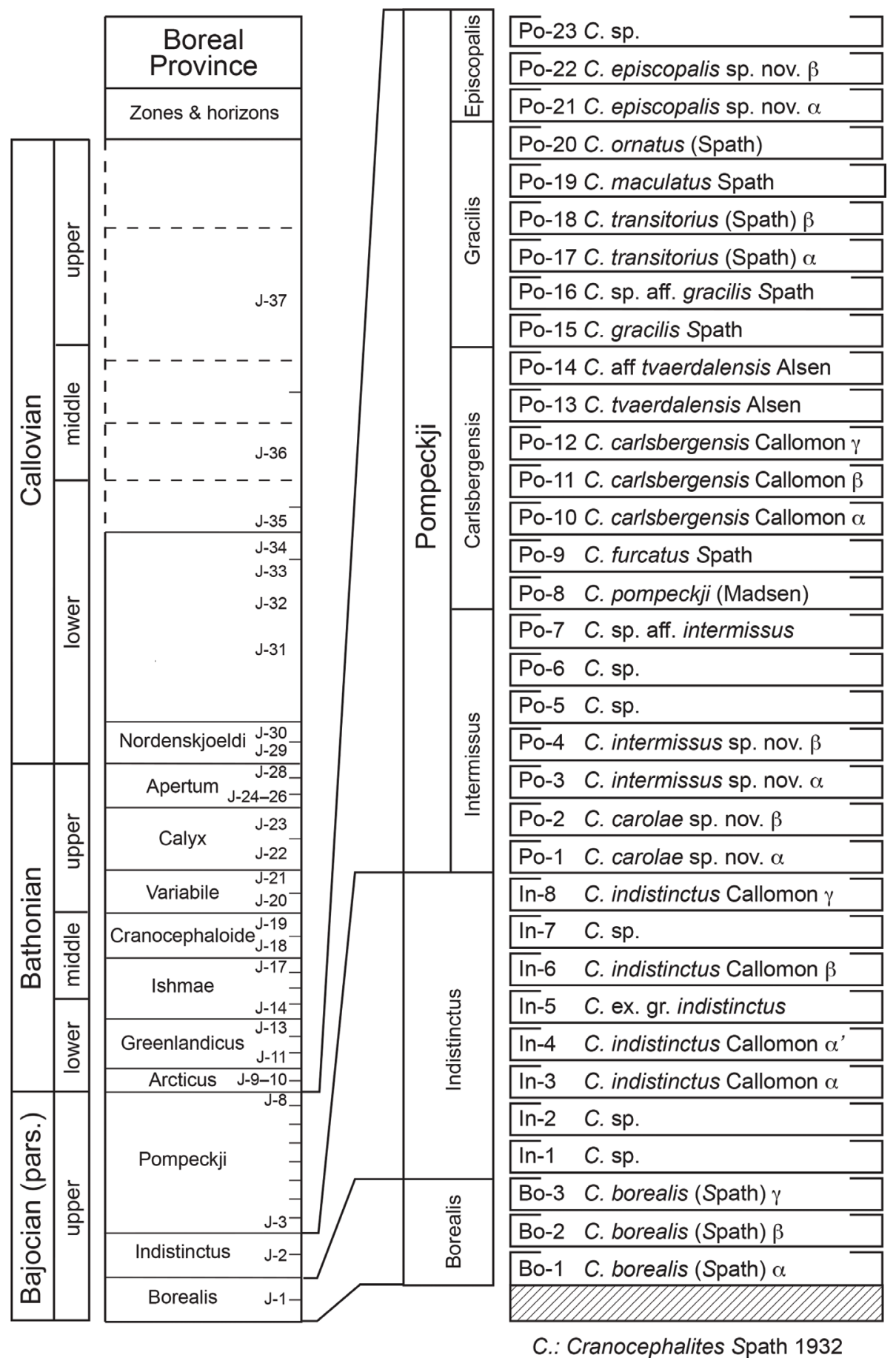

Fig. 8 Middle Jurassic ammonite zonal scheme from North-East Greenland. J-1-37: succession of ammonite faunal horizons recorded on Jameson Land by Callomon (1993). The faunal horizons of the $C$. borealis - C. pompeckji zones (J-1-8) were subsequently revised into the Bo-1-Po-23 faunal horizons shown in the expanded column to the right (Callomon et al. 2015). J: Jameson Land; Bo 1-3: faunal horizons in the Borealis Zone; In 1-8: faunal horizons in the Indistinctus Zone; Po-1-23: faunal horizons in the Pompeckji Zone. of the oldest Cranocephalites. However, upon comparison with the reference collection, it shows great resemblance with variants of Arctocephalites arcticus, which occur stratigraphically higher than the Cranocephalites of the C. pompeckji Zone found below (GEUS 545584, see previous description of C. cf. pompeckji or furcatus).

Occurrence. The specimen indicates faunal horizon J-9 of the lowermost Bathonian A. arcticus Zone (Callomon 1993; Callomon et al. 2015; Fig. 8). The species $A$. arcticus occurs in high latitudes in Franz Josef Land, northernmost Russia (Newton \& Teall 1897; Whitfield 1906), Yukon, Canada (Poulton 1987), Sverdrup Basin, Arctic Canada
(Frebold 1964), Siberia (Meledina 1973) and Pechora, Russia (Mitta 2009). A. arcticus is also found further south in the northern North Sea (Callomon 1975).

\section{Genus Arcticoceras Spath 1924 Arcticoceras ishmae (Keyserling 1846)}

Fig. $6 \mathrm{H}$

Material and horizon. One specimen, MGUH 33469 (from GEUS 545569), found in situ laterally of section JHOV$5 / 2013$, approximately level with the 10-15 m interval in the measured section (Figs 4 and 5). We obtained a mould of the relatively well-preserved left side of the specimen. 
Description. Medium-sized with little umbilicus, dense strong regular ribbing curving gently forward from the umbilical seam to the venter. Primaries bifurcate into secondaries at the mid-flank.

Occurrence. The taxon is the index species of the $A$. ishmae Zone and indicates the faunal horizon J-16 in North-East Greenland. A. ishmae is common from Jameson Land to the island of Store Koldewey, $500 \mathrm{~km}$ south of Kilen (CalIomon 1993; Callomon et al. 2015; Fig. 8). A. ishmae is recognised widely throughout the Boreal from Yukon, Canada (Poulton 1987), northern Russia (e.g. Sokolov 1912; Meledina 1987; Mitta et al. 2015), Novaya Zemlya and northern Siberia (Meledina 1973), central Russia (Mitta et al. 2011) and the northern North Sea (Callomon 1975).

Remarks. Callomon (1993) distinguished between two slightly different forms, transients a and $\beta$, of $A$. ishmae - the latter being $A$. ishmae s.s. Together with the species A. harlandi Rawson, which occurs in Svalbard, northernmost Norway (Rawson 1982; Ershova 1983), they represent faunal horizons J-14-16 in East Greenland. Based on material from a condensed section on the Russian Platform, those three taxa were suggested to be synonymous and to represent the intraspecific variation of one single variable species (Kiselev 2020a, 2020b). This is not proven for the succession in Greenland, and in this work, we follow Callomon (1993).

\section{Arcticoceras [crassiplicatum MS] Callomon?}

Material and horizon. Imprint of one specimen at $32 \mathrm{~m}$ in section JHOV-5/2013 (Figs 4 and 5). The imprint could not be collected from the section, so a rubber cast (GEUS 545588) was made.

Description. The imprint represents only a fragment of the side view of c. 1/5 of a whorl from a rather large form. The fragment is densely and fairly strongly ribbed on a broadly rounded whorl side. After comparison with specimens in the reference collection, it is tentatively referred to $A$. [crassiplicatum MS], a species, introduced by Callomon (1993), that has neither been described nor figured and type specimens have not been chosen (see Remarks).

Occurrence. A. [crassiplicatum MS] occurs in the faunal horizon J-17 in the top of the $A$. ishmae zone, middle Bathonian (Callomon 1993; Callomon et al. 2015; Fig. 8).

Remarks. The taxon A. [crassiplicatum MS] is one of a series of undescribed and unfigured MS taxa introduced by Callomon (1993). He intended to properly establish them with formal descriptions later, along with detailed accounts of their levels in the East Greenland faunal succession.
Callomon succeeded with respect to formalising the Cranocephalites taxa posthumously (Callomon et al. 2015). Several other MS-taxa unfortunately remain undescribed, but are meticulously curated in the NHMD reference collection. They have been widely integrated in the literature; for example, A. [delicatus MS] is a marker fossil of a key surface in the biostratigraphic framework for sequence stratigraphic analysis in Engkilde \& Surlyk (2003).

\section{Arcticoceras? spp. indet.}

Figs 6l, i, J and j

Material and horizon. Three specimens (all from GEUS 545568), ex situ, found in the scree slope (c. $25 \mathrm{~m}$ below section JHOV-5/2013) below the steep outcrops of Mågensfjeld Formation (Fig. 4). Illustrated specimens include MGUH 33470-33471.

Description. Specimens with projected, somewhat coarser ribbing than $A$. ishmae but less coarse than $A$. [crassiplicatum] and less involute than A. ishmae. Ribbing fades or disappears fully, and the venter becomes smooth. Specimens have been crushed, resulting in a distorted shape, but they appear to have been relatively flat or discoidal compared with $A$. ishmae. Tentatively referred to Arcticoceras.

\section{Genus Cadoceras Fischer 1882 Cadoceras cf. calyx Spath 1932}

Material and horizon. One specimen, GEUS 545589, found at $45 \mathrm{~m}$ in section JHOV-5/2013 (Figs 4 and 5). It is a fragmented, poorly preserved imprint.

Description. The fragment represents part of a relatively large shell with a relatively open umbilicus. Ribbing developed from forward curving bullae. Coarse to very coarse distant ribs on a rounded flank, which appear to be from a rounded, close to spherical whorl. Ornamentation fades and the venter appears smooth. Resembles the typical spherical forms of $C$. calyx. The preservation leaves some uncertainty, hence the cf.

Occurrence. Index species of the C. calyx Zone and occurring in faunal horizon J-23 in North-East Greenland (Callomon 1993; Callomon et al. 2015; Fig. 8). Kopik \& Wierzbowski (1988) recorded C. cf. victor from assemblage with both $C$. calyx and $C$. apertum Zones ammonites in an ironstone layer in the Janusfjellet Formation on Svalbard, Norway. Cadoceras victor was subsequently considered synonymous with C. calyx by Callomon (1993). C. calyx was reported from east Siberia by Knyazev et al. (2009) and the Russia Platform (Mitta 2005; Kiselev \& Rogov 2007). 


\section{Cadoceras apertum Callomon \& Birkelund 1985}

Material and horizon. One specimen, GEUS 545590, found at $72 \mathrm{~m}$ in a poorly exposed part of the section JHOV-5/2013 (Figs 4 and 5). Fragment.

Description. The fragment is c. 1/5 of a whorl. Only the upper part of one side of the whorl and the venter are preserved. It is totally smooth. The venter is relatively narrow and arched. It does not resemble the thickwhorled holotype of $C$. apertum, but the reference collection includes smooth macroconch variants with slender, narrowly rounded venter.

Occurrence. Index of the C. apertum Zone in East Greenland, faunal horizon J-24-26 (Callomon 1993; Callomon et al. 2015; Fig. 8). Outside Greenland, the taxon occurs in the Janusfjellet Formation, Svalbard (Kopik \& Wierzbowski 1988) and Russia (Mitta 2005).

\section{Family Kosmoceratidae Haug 1887}

Genus Kepplerites Neumayr \& Uhlig 1892

Kepplerites cf. traillensis Donovan 1953 or K. chisikensis Imlay 1975

Fig. 7

Material and horizon. One specimen, MGUH 33472 (from GEUS 545591), consists of part of the internal mould/ steinkern only and imprints of the rest of the specimen, which are crushed and incomplete. Found at c. $80 \mathrm{~m}$ height in section JHOV-5/2013 (Figs 4 and 5).

Description. The last whorl is clearly uncoiling, showing the specimen to be an adult. Maximum diameter is $131.5 \mathrm{~mm}$. Ribbing is fine and dense. Primary ribs are relatively prominent compared with the secondaries. It begins slightly rursiradiate to rectiradiate before crossing the gently sloping umbilical wall and shoulder with a gentle forward bend and becomes slightly prorsiradiate. The projection increases near the end or final peristome. The primary ribs divide low, about one-third, up the flank into forward leaning sheaves of four straight, evenly spaced and equally strong secondaries.

Comparisons. The specimen is close to both $K$. traillensis and $K$. chisikensis. The latter includes Kepplerites tenuifasciculatus described from East Greenland (Callomon 2004), but $K$. tenuifasciculatus was recently considered a junior synonym of $K$. chisikensis Imlay by Mönnig \& Dietl (2017). K. traillensis is less densely ribbed than $K$. chisikensis; at last septum, $K$. traillensis has 31 primaries per whorl, whereas K. chisikensis has 40 (Callomon 2004). The collected specimen is too poorly preserved to be identified as either of those two species. Hence, it is referred to as $K$. cf. traillensis or K. chisikensis. The species Kepplerites vardekloeftensis Callomon has coarser secondaries and ornamentation that fades on the last body chamber. Adult Kepplerites svalbardensis Sokolov \& Bodylevsky is generally smaller. The studied specimen resembles $K$. svalbardensis in coiling and ribbing density. However, $K$. svalbardensis is smaller, and its ribbing differs in becoming backwards, curving on the upper flank, after the initial forward curving on the lower flank and after crossing the umbilical shoulder. Lastly, the specimen from Mågensfjeld is also close to some variants of $K$. keppleri (Oppel) with relatively delicate primaries (e.g. Quenstedt 1887, plate 77, Fig. 3; Tintant 1963, plate 1; Page 1989, Figs 5.1a, b) but differs from those with relatively coarser primaries (e.g. Tintant 1963, plate 2; Dietl \& Gygi 1998, plate 1a).

Occurrence. K. chisikensis and $K$. traillensis indicate the faunal horizons J-24-27 in the C. apertum Zone (Callomon 1993, 2004; Fig. 8). Note that this zone was initially considered as Callovian, based on strong resemblance of Kepplerites from this zone with $K$. keppleri, the appearance of which defines the base of the Callovian in Europe (Callomon 1993; Mönnig \& Dietl 2017). Mitta \& Alsen (2013) tentatively placed the $C$. apertum Zone in the upper Bathonian, based on late Bathonian ornamentation recorded in material above $K$. "tenuifasciculatus." Considering that ornamentation in the genus developed progressively or regressively (Callomon 2004), thick ribs do not unequivocally demonstrate a Bathonian age. Reference of the $C$. apertum Zone to the Bathonian was supported by Mönnig \& Dietl (2017). Kepplerites dietli Schairer is considered a junior synonym of $K$. traillensis that correlates the Greenland faunal horizon J-26 of Callomon (1993) in the C. apertum Zone to the lower part of the $C$. discus Zone in Germany. The $K$. aff. traillensis in faunal horizon $\mathrm{J}-28$ is considered synonymous with $K$. radiatus Sakharov \& Lominadze and thus correlates to the upper part of the $C$. discus Zone (Mönnig \& Dietl 2017). The possible presence of $K$. keppleri in the faunal horizon J-29 in the Nordenskjoeldi Zone would provide correlation to the base Callovian $K$. keppleri fauna, defining the base of the Callovian in Europe (Mönnig \& Dietl 2017; Fig. 8). If the present specimen is actually $K$. keppleri, which cannot be determined from its preservation, it would be indicative of the fauna J-29-30 in the Nordenskjoeldi Zone and the base Callovian. This fits with the studied section where it was found somewhat above C. apertum of the Apertum Zone (Fig. 5).

\subsection{Biostratigraphic summary}

The biostratigraphy at Mågensfjeld can be summarised as follows:

1. Late Bajocian Cranocephalites cf. pompeckji or C. furcatus represents the Po-8 or Po-9 faunal horizons of the C. pompeckji Zone (Callomon et al. 2015).

2. Bathonian Arctocephalites cf. arcticus represents the J-9 faunal horizon of the A. arcticus Zone. 
3. Bathonian Arcticoceras ishmae and Arcticoceras [crassiplicatum] of the J-16 and J-17 horizons represent the A. ishmae Zone (Callomon 1993; Callomon et al. 2015).

4. The upper Bathonian C. calyx and C. apertum Zone are represented by a relatively thick interval ranging from the middle of the section to near the top of the outcrop. The ammonites include C. calyx, indicating the J-23 horizon, $C$. apertum of the J-2426 horizons and Kepplerites cf. traillensis or chisikensis of the J-27 horizon (Callomon 1993; Callomon et al. 2015; Fig. 7).

Nygaard (2003) recorded one loose Cranocephalites aff. borealis found loose in Kilen in an "area covered by Upper Cretaceous sediment" (Nygaard 2003, p. 6). It was
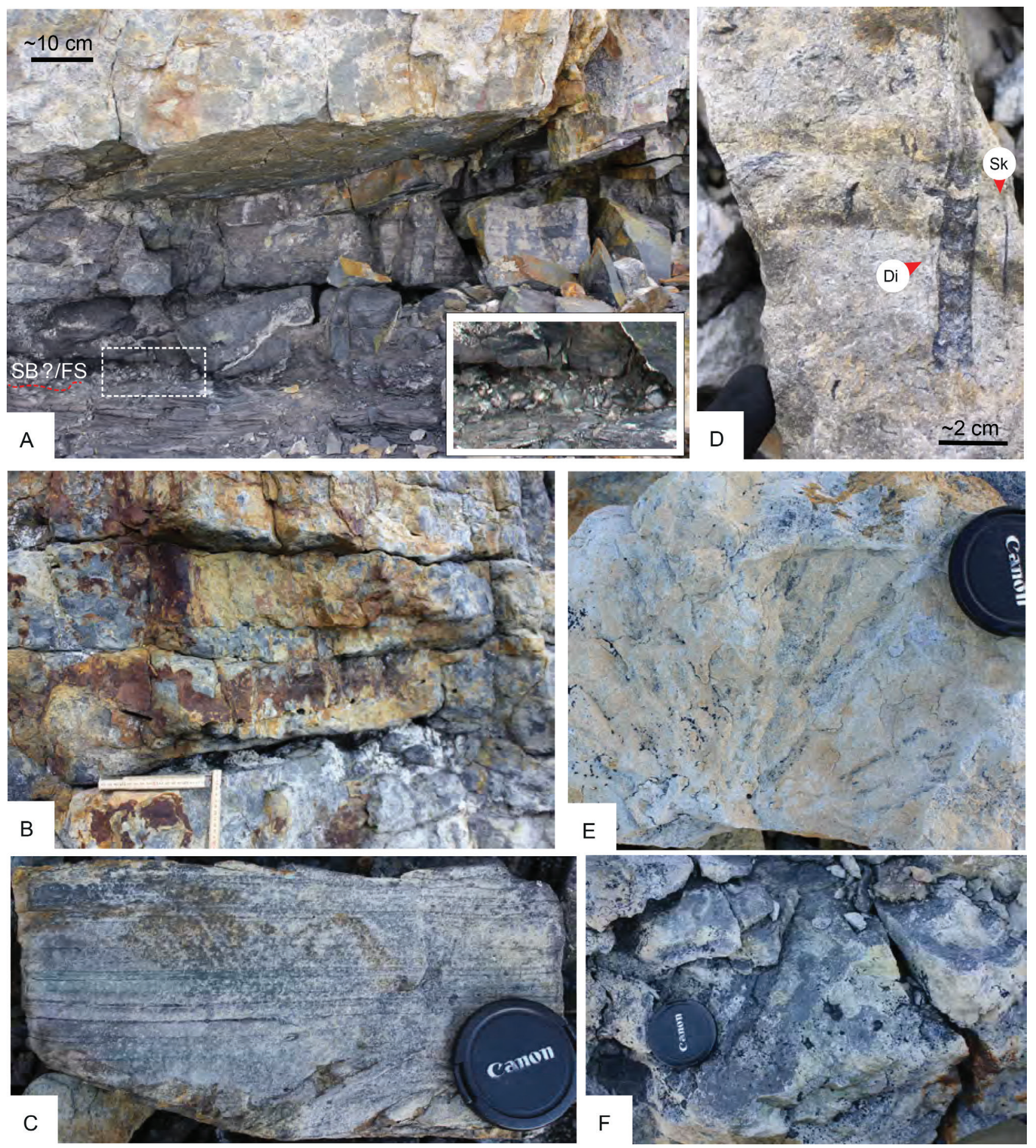

Fig. 9 Examples of facies from the Mågensfjeld Formation. A: Base of the succession showing the contact between facies association (FA) 1-2. SB: possible sequence boundary; FS: flooding surface. B: Typical coated expression of tabular beds of FA 2. C: Parallel-laminated sandstone that grades upwards into ripple cross-lamination, FA 2. D-F: Typical trace fossils of Mågensfjeld Formation. D: Diplocraterion isp. (Di) and Skolithos isp. (Sk) burrowing into burrow-mottled fine-grained sandstone. E: Bedding plane view to radiating burrow arms of Phoebichnus isp. F: Rhizocorallium isp. in fine-grained sandstone. 
likely found beneath Mågensfjeld. The ammonite faunas described in the present study occur in the steep well-exposed cliffs in the top of the Mågensfjeld, but the scree-covered lower flanks of the hill leave room for older deposits - and a Cranocephalites borealis bearing horizon.

\section{Depositional setting}

The Mågenfjeld Formation outcrop is characterised by a weathered rock surface with a pale coating that commonly hinders detailed sedimentological data collection. Tentatively, the succession is divided into three facies associations (FA 1-3; Figs 8 and 9).

\subsection{Facies association 1: fluvial or fluviotidal? 6.1.1 Description}

FA 1 has a single occurrence at the base of the Mågensfjeld Formation succession. The deposits are poorly exposed and only a few metres can be studied in any detail. The unit is sharply overlain by FA 2 (see Section 6.2; Fig. 9A), but the lower boundary was not observed. The observable facies includes a few centimetre-thick, unbioturbated, mud-clast-bearing, fine-grained sandstone beds and lenticular bedding that is rich in plant debris. The mud-clasts are commonly concentrated at the base of the bed. The top of FA 1 is demarcated by an erosion-based extraformational pebble bed, a few centimetres thick.

\subsubsection{Interpretation}

Due to the limited data, we do not attempt to make a detailed palaeoenvironmental interpretation of FA 1, and the following discussion is considered tentative.

Lack of bioturbation in a periodically, relatively low-energy setting (e.g. post-event bed boundaries) may suggest that the endobenthic colonisation was limited by the freshwater setting. The upper erosional boundary and abrupt change in grain size from fine-grained sandstone to pebbles suggest truncation and development of an erosional lag. Such a surface may form, for instance, as a result of lateral changes in channel position in fluvial, estuarine or deltaic environments, or as a result of a progradational jump (even forced regression), and therefore could represent a sequence boundary. Furthermore, considering that the overlying deposits (FA 2) are marine, the surface is also associated with deepening. In summary, considering the aforementioned observations and the stratigraphic position below FA 2, the deposits are broadly interpreted to represent a fluvial or fluviotidal environment. The top of FA 1 represents a flooding surface and possibly a sequence boundary.

\subsection{Facies association 2: delta front 6.2.1 Description}

FA 2 is a common facies association type in the lower and middle parts of the Mågensfjeld Formation. It forms aggradational to slightly upwards coarsening successions up to $10 \mathrm{~m}$ thick, which comprise decimetre-scale, tabular fine-grained sandstone beds (Figs 9B and C). The lower contact of FA 2 is sharp, and the limited exposure suggests a down-lapping pattern onto FA 3 (see Section 6.3) or FA 1. The upper contact to FA 3 is either sharp or gradational. The rock surface is usually covered hindering systematic data collection, but where observable, the beds are structureless or show parallel lamination capped with ripple-cross lamination (Fig. 9C). The beds show straight or trough-shaped bases. The beds appear to pinch-out towards the south-east. Similarly, sporadic palaeocurrent measurements tentatively suggest southsouth-east oriented flow $(n=3)$. Bioturbation is commonly sporadic (bioturbation index 0-2, locally higher) and concentrated towards the top of the beds (data not shown). The suites are of low diversity and consist predominantly of vertical to inclined trace fossils such as Diplocraterion isp., Skolithos isp. and ?Siphonichnus isp. (Fig. 9D). Sub-millimetre to millimetre-scale mud-filled branching burrows (?Chondrites) and indistinct burrow mottling are locally present. Plant fragments are common and include complete leaves. Reworked belemnites are locally concentrated at the base of the beds.

\subsubsection{Interpretation}

The trace fossil assemblage and the occurrence of marine fossils such as belemnites point to a general shallow marine setting. Tabular beds showing parallel lamination to ripple cross lamination may suggest an origin of a shallow marine gravity flow, whereas wave-generated structures are rare. Putative downlapping, the pinch-out nature of the beds and the presence of deposits, rich in plant material supports a distal delta front setting.

\subsection{Facies association 3: protected shoreface}

\subsubsection{Description}

FA 3 is a common facies association type in the middle and upper parts of the formation. It overlies FA 2 sharply or gradationally and is sharply overlain by the same association, where observable. The association forms aggradational or faintly upwards coarsening successions, comprised of bioturbated fine-grained sandstone. Distal expressions consist of intensively bioturbated muddy, very fine- to fine-grained sandstone. Common trace fossils include indistinct mud-filled grazing structures (?Helminthopsis isp. and Nereites isp.), mud-filled branching burrows (?Chondrites), Palaeophycus tubularis and ?Siphonichnus isp. Proximal expressions consist of fine-grained sandstone burrowed with a low to moderate diversity assemblage, showing recurring Phoebichnus isp., Rhizocorallium isp., Thalassinoides isp., Diplocraterion isp., Skolithos isp. and ?Siphonichnus isp. in addition to aforementioned structures (Figs $9 \mathrm{E}$ and F). Wave ripples and dune-scale cross bedding are rarely observed. 


\subsubsection{Interpretation}

The trace fossil content generally points to a relatively low-energy, shallow marine environment periodically influenced by small-scale event sedimentation. The high bioturbation intensity and scarcity of preserved waveor storm-generated structures probably point to a confined setting, where oscillation currents are subdued. FA 3 is burrowed with elements of the Cruziana ichnofacies, with increasing contribution of elements of the Skolithos ichnofacies towards proximal expressions and is interpreted to represent protected lower to middle shoreface-like environments.

\subsection{Summary}

In summary, FA 1 is recorded lowest in the measured section between 0 and $2 \mathrm{~m}$, whereas the remaining overlying section belongs to alternations of FA 2 and FA 3. Overall, the succession reflects a backstepping to aggradational depositional evolution with a putative fluvial or fluviotidal base, overlain by deltaic and protected shoreface facies.

\section{Discussion}

\subsection{Stratigraphic relations in Kilen}

The Mågensfjeld Formation is only well-exposed at Mågensfjeld, on the upper slopes of the mountain. Below the exposures, the slope is covered by scree composed of blocks and slabs of thermally altered sandstone weathered out from the Mågensfjeld Formation. The scree covers the boundary to the underlying Gletscherport Formation, which has a restricted exposure near the foot of the slope towards the Hondal valley (Hovikoski et al. 2018; Fig. 2). The orientation of the strata of the Mågensfjeld Formation is close to horizontal (Figs 3 and 4), whereas the strata of the Gletscherport Formation are steeply dipping (up to $70^{\circ}$ ) towards the east. This is most likely due to fault drag as the Gletcherport Formation is exposed just west of the inferred position of a large normal fault in the Hondal valley (Normal Fault II of Svennevig et al. 2016). The fault has downthrown the mid- to Upper Cretaceous succession at Saddelfjeld to the east, relative to the Middle Jurassic succession at Mågensfjeld to the west. An alternative explanation for the marked difference in orientation between the Mågensfjeld and the Gletscherport formations could be an angular unconformity between the two units, covered by the scree, indicating a marked structural event between the depositions of the two units. However, we consider the fault drag explanation to be the most plausible.

The upper boundary of the Mågensfjeld Formation is not exposed. The succeeding unit in the Kilen succession is the Birkelund Fjeld Formation, which has yielded Kimmeridgian ammonites (Hovikoski et al. 2018). The lower part of the Birkelund Fjeld Formation is not exposed in outcrop, and the age of its base is thus unknown.
This leaves open the possibility of a depositional gap between the two formations, or for the presence of Callovian-Oxfordian strata in the interval between the Bathonian of the Mågensfjeld Formation and the Kimmeridgian, upper part, of the Birkelund Fjeld Formation.

\subsection{Middle Jurassic in the neighbouring high Arctic \\ 7.2.1 North-East Greenland}

The nearest Middle Jurassic ammonite-bearing succession in Greenland is the Pelion Formation on Store Koldewey island (c. $76^{\circ} \mathrm{N}$, North-East Greenland), where a rich ammonite fauna represents the Bathonian-Callovian (Ravn 1911; Piasecki et al. 2004). The Pelion Formation is a widespread deltaic to shallow marine sandstone unit with outcrops south of Store Koldewey on Hochstetter Forland, Kuhn $\varnothing$, Wollaston Forland, Hold with Hope, Geographical Society $\varnothing$, Traill $\varnothing$ and as far south as Jameson Land (see Surlyk 2003; Surlyk et al. in press). A report of $C$. aff. borealis in Kilen indicated that Middle Jurassic deposition commenced in the $C$. borealis chron (Nygaard 2003). This would be isochronous with the onset of the huge marine flooding and deposition of the sand-dominated, shallow marine and deltaic system of the Pelion Formation (Callomon 1993; Surlyk 2003). The Pelion Formation probably extends offshore into the Danmarkshavn Basin north of Store Koldewey.

\subsubsection{Peary Land}

Middle Jurassic deposits may be present on Peary Land, making them the closest to Kilen. Håkansson \& Pedersen (2015) subdivided the sedimentary succession of the Wandel Sea Basin into a series of separate, discrete basins, many of which they considered to be formed by strike-slip movements within the Kronprins Christian Land strike-slip mobile belt. In one restricted area of Sildredome, eastern Peary Land (Fig. 1), lies the so-called Sildredome Basin - so-named by Håkansson \& Pedersen (2015). The area is a few square kilometres in size and contains a fault complex. Numerous Middle Jurassic C. pompeckji Zone ammonites have been recorded in the area (Nygaard 2003; Håkansson \& Pedersen 2015) and found loose on a weathered surface mapped as the Ladegårdsåen Formation, Peary Land (Kokfelt et al. 2013). More than 20 such specimens have been counted from this small area, which is strongly indicative of the Middle Jurassic (upper Bajocian). However, outcrops are yet to be discovered. The oldest age of the Ladegårdsåen Formation has so far been dated middle Oxfordian (Håkansson et al. 1981; Dypvik et al. 2002).

\subsubsection{Svalbard}

Today, Svalbard and the Barents shelf are more than 600 $\mathrm{km}$ away from Kilen, but prior to the opening of the Atlantic, they were only 400 and 200 km away, respectively 
(Svennevig et al. 2017, using Müller et al. 2016). The closest (onshore) correlative unit to the Wandel Sea Basin, geologically speaking, is probably found on Svalbard.

Middle Jurassic ammonites have been reported from Svalbard in the Oppdalen Member of the lower part of the Agardhfjellet Formation, immediately above thin (decimetre to a few metres thick) remanié deposits of the Brentskardhaugen Bed (Birkenmajer 1980; Birkenmajer et al. 1982). The Brentskardhaugen Bed is a conglomerate with reworked concretions containing Toarcian, Aalenian and Bajocian fossils (Bäckström \& Nagy 1985). Dypvik et al. (1991a, 1991b) considered the Brentskardhaugen Bed deposited close to the Bathonian-Callovian transition. However, that age is in conflict with the occurrence of Cranocephaloide Zone ammonites in the overlying Agardhfjellet Formation (Kopik \& Wierzbowski 1988). The Cranocephaloide Zone is now considered middle Bathonian (Callomon et al. 2015). The Agardhfjellet Formation is up to $290 \mathrm{~m}$ thick and is Bathonian to Ryazanian. The lower Oppdalen Member is a silt and fine-sand-dominated unit, 10-60 m thick and relatively coarse compared to the dominantly papershales of the Agardhfjellet Formation (Mørk et al. 1999). Kopik \& Wierzbowski (1988) reported a succession of three assemblages from the lower $10 \mathrm{~m}$ of the Oppdalen Member of middle Bathonian Cranocephaloide Zone, Calyx-Apertum Zones and Callovian Coronatum-Athleta Zones, respectively, with several taxa related to those reported here from Kilen, North Greenland.

The documentation of a Middle Jurassic sandstone unit in Kilen provides an important data point for sandstone deposition and a reservoir unit analogue in the region. Kilen is part of the same depositional system as the northern part of the Store Koldewey platform bordering the Danmarkshavn Basin in the offshore area east and north of Store Koldewey island. The Danmarkshavn Basin was recently subject to petroleum exploration with five licence blocks issued. The Mågensfjeld Formation may be a more closely fitting analogue for sandstone units in the western Barents Sea (e.g. Stø Formation; Olaussen et al. 1984; Gjelberg et al. 1987; Klausen et al. 2019) than the onshore analogues on Svalbard.

The presence of Bajocian-Bathonian shallow marine deposits in Kilen shows that the Wandel Sea Basin was influenced by the Middle Jurassic transgression and had sufficient accommodation space for marine deposition earlier than previously thought (cf. Dypvik et al. 2002). The palaeoenvironmental characteristics of the Middle Jurassic Mågensfjeld Formation and Upper Jurassic (Kimmeridgian) Birkelund Fjeld Formation in Kilen are strikingly similar. Both are comprised mainly of protected shallow marine and deltaic environments and show generally an aggradational stacking pattern. However, a deepening trend from a fluvial, fluviotidal and deltaic environment to a protected shoreface occurs in the Bajocian interval.

\subsection{Structural implications}

The new Middle Jurassic age for the Mågensfjeld Formation greatly simplifies the structural complexity of the area. The previous Late Cretaceous age called for the introduction of a large inferred reverse fault, bringing the Late Jurassic Kuglelejet Formation in contact with the previously dated Late Cretaceous Mågensfjeld Formation (Pedersen 1991; Håkansson et al. 1993; Fig. 2). Using the estimated thicknesses of the formations (Hovikoski et al. 2018; Svennevig et al. 2016), the vertical throw on the suggested fault would have been around $2000 \mathrm{~m}$ - by far the largest known from the area. The age of the Mågensfjeld Formation presented here, along with mapping from oblique photogrammetry and 3D modelling (Svennevig et al. 2015, 2016), demonstrate a simple, gentle and upright anticline with the Middle Jurassic Mågensfjeld at the core, truncated by a normal fault to the east and covered by ice to the west and north (Svennevig 2018; Figs 1 and 2). The normal fault is presumably of latest Cretaceous age and predates the Eurekan folding that likely occurred during the Paleocene-Eocene (Svennevig et al. 2016).

\section{Conclusions}

The sandstone succession exposed in the steep cliffs of Mågensfjeld, belonging to the Mågensfjeld Formation, records generally shallow marine depositional environments. The succession is fossil bearing, and the ammonites belonging to the genera Cranocephalites, Arctocephalites, Arcticoceras, Cadoceras and Kepplerites show a great affinity to the Middle Jurassic faunal succession in North-East Greenland. The ammonites allow the identification of the Bajocian C. pompeckji Zone, the Bathonian $A$. arcticus, A. ishmae, C. calyx and C. apertum Zones.

The Middle Jurassic age of the unit allows for a much more straightforward model of the structural evolution of this area of Kilen, compared with the previously proposed Late Cretaceous age. The structural evolution essentially records Late Cretaceous extension followed by Palaeogene folding (probably Eurekan, Paleocene-Eocene).

The deposition of the Mågensfjeld Formation records Middle Jurassic transgression in the Wandel Sea Basin and the development of accommodation space for marine deposition of a sand-dominated unit. The age of the unit is equivalent to the well-described reservoir unit analogues of the Middle Jurassic in North-East Greenland (e.g. Pelion Formation, Store Koldewey). As such, the Mågensfjeld Formation serves as a key datapoint and analogue for possible Middle Jurassic units in offshore basins; for example, in the western Barents Sea, the Wandel Sea and the Danmarkshavn Basins.

\section{Acknowledgements}

We thank Jette Halskov for drafting of Figs 1, 2, 4, 5 and 8. We appreciate the useful comments of the two reviewers, M. Rogov and one anonymous reviewer, which greatly improved the final manuscript. 


\section{Additional information}

\section{Funding statement}

Data were collected during the field work funded by the Geological Survey of Denmark and Greenland (GEUS) and undertaken within the collaboration project "Petroleum Geological Studies, Services and Data in East and North-East Greenland."

\section{Author contributions}

PA: conceptualisation. PA, JH and KS: formal analysis, investigation, writing - original draft, writing - review and editing.

\section{Competing interests}

The authors declare no competing interests

\section{Additional files}

None provided.

\section{References}

Alsen, P. 2000: Middle Jurassic ammonite biostratigraphy in the Traill $\varnothing$ region North-East Greenland, 104 pp. Unpublished Master's thesis, University of Copenhagen.

Alsen, P. et al. 2017: The Isrand formation: a Middle Triassic Daonella-bearing, black shale unit in Kilen, North Greenland (with a note on the Triassic in Amdrup Land). Newsletters in Stratigraphy 50, 31-46. https://dx.doi.org/10.1127/nos/2016/0341

Bäckström, S.A. \& Nagy, J. 1985: Depositional history and fauna of a Jurassic phosphorite conglomerate (the Brentskardhaugen Bed) in Spitsbergen. Norsk Polarinstitutt Skrifter 183, 61.

Birkelund, T. \& Håkansson, E. 1983: The Cretaceous of North Greenland - a stratigraphic and biogeographical analysis. Zitteliana 10, 7-25.

Birkenmajer, K. 1980: Jurassic-Lower Cretaceous succession at Agardhbukta, East Spitsbergen. Studia Geologica Polonica 66, 35-52.

Birkenmajer, K., Pugaczewska, H. \& Wierzbowski, A. 1982: The Janusfjellet Formation (Jurassic-Lower Cretaceous) at Myklegardfjellet, East Spitsbergen. Palaeontologia Polonica 43, 107-140.

Bojesen-Koefoed, J., Alsen, P. \& Christiansen, F.G. 2014: Six years of petroleum geological activities in North-East Greenland (2008-2013): projects and a view of the future. Geological Survey of Denmark and Greenland Bulletin 31, 59-62. https://dx.doi.org/10.34194/geusb. v31.4661

Callomon, J.H. 1961: The Jurassic system in East Greenland. In: Raasch, G.O (ed.): Geology of the Arctic, 258-268. Toronto: University of Toronto Press. https://dx.doi.org/10.3138/9781487584979-024

Callomon, J.H. 1975: Jurassic ammonites from the northern North Sea. Norsk Geologisk Tidsskrift 55, 373-386.

Callomon, J.H. 1985: The evolution of the Jurassic ammonite family Cardioceratidae. In: Cope, J.C.W. \& Skelton, P.W. (eds): Evolutionary case stories from the fossil record. Special Papers in Palaeontology 33, 49-90. London: Palaeontological Association.

Callomon, J.H. 1993: The ammonite succession in the Middle Jurassic of East Greenland. Bulletin of the Geological Society of Denmark 40, 83-113.

Callomon, J.H. 2004: Description of a new species of ammonite, Kepplerites tenuifasciculatus n. sp. from the Middle Jurassic, Lower Callovian of East Greenland. Appendix in Alsen \& Surlyk: maximum Middle Jurassic transgression in East Greenland: evidence from new ammonite finds, Bjørnedal, Traill $\varnothing$. Geological Survey of Denmark and Greenland Bulletin 5, 31-49. https://dx.doi.org/10.34194/geusb.v5.4806

Callomon, J.H., Alsen, P. \& Surlyk, F. 2015: The ammonites of the Middle Jurassic Cranocephalites-beds of East Greenland. The Geological Survey of Denmark and Greenland Bulletin 34, 145 pp. https://dx.doi. org/10.34194/geusb.v34.4488

Cherkesov, O.V. \& Burdykina, M.D. 1979: Description of the new ammonite records from the Novaya Zemlya. In: Shulgina, N.I. (ed.): Upper Palaeozoic and Mesozoic of islands and coast of Arctic seas of the USSR Nauchn. Issled. Inst. Geol. Arctic Publ, Leningrad, 43-66 (in Russian).

Dawes, P. 1976: Precambrian to Tertiary of northern Greenland. In: Escher, A. \& Watt, W.S. (eds): Geology of Greenland, 248-303. Copenhagen: Geological Survey of Greenland.
Dawes, P. \& Peel, J. 1981: The northern margin of Greenland from Baffin Bay to the Greenland Sea. In: Nairn, A.E.M. et al. (eds): The Arctic Ocean, 201-364. New York, NY: Plenum Press. https://dx.doi. org/10.1007/978-1-4757-1248-3_5

Dawes, P. \& Soper, J. 1973: Pre-Quarternary history of North Greenland. In: Pitcher, M.G. (ed.): Arctic Geology. AAPG Memoir 19, 117-134.

Dietl, G. \& Gygi, R. 1998: Die Basis des Callovian (Mittlerer Jura) bei Liesberg BL, Nordschweiz. Eclogae geologicae Helvetiae 91, 247-260.

Donovan, D.T. 1953: The Jurassic and Cretaceous stratigraphy and palaeontology of Traill $\varnothing$, East Greenland. Meddelelser om Grønland 111, 150.

Donovan, D.T. 1957: The Jurassic and Cretaceous systems in East Greenland. Meddelelser om Grønland 155, 214

Dypvik, H., et al. 1991a: Depositional conditions of the Bathonian to Hauterivian Janusfjellet Subgroup, Spitsbergen. Sedimentary Geology 72, 55-78. https://dx.doi.org/10.1016/0037-0738(91)90123-u

Dypvik, H., et al. 1991b: The Janusfjellet Subgroup (Bathonian to Hauterivian) on central Spitsbergen: a revised lithostratigraphy. Polar Research 9(1), 21-43. https://dx.doi.org/10.1111/j.1751-8369.1991. tb00400.x

Dypvik, H., Håkansson, E. \& Heinberg, C. 2002: Jurassic and Cretaceous palaeogeography and stratigraphic comparisons in the North Greenland-Svalbard region. Polar Research 21, 91-108. https://dx.doi. org/10.3402/polar.v21i1.6476

Engkilde, M. \& Surlyk, F. 2003: Shallow marine syn-rift sedimentation: middle Jurassic Pelion Formation, Jameson Land, East Greenland. In: Ineson, J. \& Surlyk, F. (eds): The Jurassic of Denmark and Greenland. Geological Survey of Denmark \& Greenland Bulletin 1, 813-864. https://dx.doi.org/10.34194/geusb.v1.4690

Ershova, E.S. 1983: Explanatory notes for the biostratigraphical scheme of the Jurassic and Lower Cretaceous deposits of Spitzbergen archipelago. 88 pp. Leningrad, PGO Sevmorgeologia. (in Russian).

Frebold, H. 1964: The Jurassic faunas of the Canadian Arctic Cadoceratinae. Geological Survey of Canada Bulletin 119, 27 pp. +20 plates. https://dx.doi.org/10.4095/100627

Gjelberg, J., Dreyer, T., Høie, A., Tjelland, T. \& Lilleng, T. 1987: Late Triassic to Mid-Jurassic sandbody development on the Barents and Mid-Norwegian shelf. In: Brooks, J. \& Glennie, K.W. (eds): Petroleum Geology of North West Europe, 1105-1129. London: Geological Society.

Haller, J. 1970: Tectonic map of East Greenland (1: 500 000): an account of tectonism, plutonism, and volcanism in East Greenland. Meddelelser om Grønland 171, 1-260.

Hovikoski, J. et al. 2018: The Jurassic-Cretaceous lithostratigraphy of Kilen, Kronprins Christian Land, eastern North Greenland. Bulletin of the Geological Society of Denmark 66, 61-112.

Håkansson, E. 1994: Scaphitid ammonoids and inoceramids bivalves from Upper Cretaceous strata in North Greenland. Scientific report 14. In: Wandel Sea Basin: Basin Analysis. EFP-91, Project No. 0012, Completion Report to the Ministry of Energy, 13 pp. Copenhagen: University of Copenhagen.

Håkansson, E. \& Pedersen, S.A.S. 2001: The Wandel Hav Strike-Slip Mobile Belt - a Mesozoic plate boundary in North Greenland. Bulletin of the Geological Society of Denmark 48, 149-158.

Håkansson, E. \& Pedersen, S.A.S. 2015: A healed strike-slip plate boundary in North Greenland indicated through associated pull-apart basins. Geological Society (London) Special Publications 413, $143-$ 169. https://dx.doi.org/10.1144/sp413.10

Håkansson, E. \& Stemmerik, L. 1989: Wandel Sea basin - a new synthesis of the late Paleozoic to Tertiary accumulation in North Greenland. Geology 17, 683-686. https://dx.doi.org/10.1130/0091-7613(1989)01 7<0683:WSBANS>2.3.CO;2

Håkansson, E., Birkelund, T., Piasecki, S. \& Zakharov, V. 1981a: Jurassic Cretaceous boundary strata of the extreme Arctic (Peary Land, North Greenland). Bulletin of the Geological Society of Denmark 30, 11-42.

Håkansson, E., Heinberg, C. \& Stemmerik, L. 1981b: The Wandel Sea Basin from Holm Land to Lockwood $\varnothing$, eastern North Greenland. Grønlands Geologiske Undersøgelse Rapport 106, 47-63.

Håkansson, E., Heinberg, C. \& Stemmerik, L. 1991: Mesozoic and Cenozoic history of the Wandel Sea Basin area, North Greenland. Grønlands Geologiske Undersøgelse Bulletin 160, 153-164. 
Håkansson, E., et al. 1993: The Kilen Expedition 1985. Bulletin of the Geological Society of Denmark 40, 9-32.

Håkansson, E., Heinberg, C., Pedersen, S.A.S. 1994: Geology of Kilen. Scientific report 16. In: Wandel Sea Basin: Basin Analysis. EFP-91, Project No. 0012, Completion Report to the Ministry of Energy, 13 pp. Copenhagen: University of Copenhagen.

Imlay, R.W. 1962: Jurassic (Bathonian or Early Callovian) ammonites from Alaska and Montana. Geological Survey (US) Professional Paper 374-C, 32 pp. https://dx.doi.org/10.3133/pp374c

Kiselev, D.N. 2020a: Morphogenesis rate variability and modularity of development in Jurassic ammonites of the genus Arcticoceras Spath, 1924. Paleontological Journal 54 (19) 20-33. https://dx.doi. org/10.1134/s0031030120010050

Kiselev, D.N. 2020b: Genus Arcticoceras Spath, 1924 (Ammonoidea) and infrazonal biostratigraphy of the lower Bathonian of the Boreal Realm. Stratigraphy and Geological Correlation 28, 177-201. https:// dx.doi.org/10.1134/s086959382002001x

Kiselev, D.N. \& Rogov, M.A. 2007: Stratigraphy of the Bathonian-Callovian boundary deposits in the Prosek Section (middle Volga Region). Article 1. Ammonites and infrazonal biostratigraphy. Stratigraphy and Geological Correlation 15, 485-515. https://dx.doi.org/10.1134/ s0869593807050036

Klausen, T.G., Müller, R., Poyatos-Moré, M., Olaussen, S. \& Stueland, E. 2019: Tectonic, provenance and sedimentological controls on reservoir characteristics in the Upper Triassic-Middle Jurassic Realgrunnen Subgroup, SW Barents Sea. In: Chiarella, D. et al. (eds): Cross-Border Themes in Petroleum Geology II: Atlantic Margin and Barents Sea. Geological Society (London) Special Publications 495, 25 pp. https:// dx.doi.org/10.1144/SP495-2018-165

Knyazev, V.G., Kutygin, R.V. \& Meledina, S.V. 2009: The upper Bathonian ammonite zonation of east Siberia. Stratigraphy and Geological Correlation 17, 192-203. https://dx.doi.org/10.1134/s0869593809020075

Kokfelt, T.F., Keulen, N.T., Weng, W.L. \& Pedersen, M. 2013: Geological map of Greenland, 1:500 000. Copenhagen: Geological Survey of Denmark and Greenland. https://www.greenmin.gl. (Accessed: April 2013)

Kopik, J. \& Wierzbowski, A. 1988: Ammonites and stratigraphy of the Bathonian and Callovian at Janusfjellet and Wimanfjellet, Sassenfjorden, Spitsbergen. Acta Palaeontologica Polonica 33, 145-168.

Meledina, S.V. 1973: Ammonites and zonal stratigraphy of the BajocianBathonian of Siberia. Trudy Institut Geologii I Geofiziki, Akademiya Nauk SSSR, Sibirskoe otdelenie 153, 152 pp. (in Russian)

Meledina, S.V. 1987: Ammonites and zonal stratigraphy of the Callovian of the subboreal regions of the USSR. Trudy Institut Geologii I Geofiziki, Akademiya Nauk SSSR, Sibirskoe otdelenie 691, 184 pp. (in Russian)

Mitta, V. 2005: Late Bathonian Cardioceratidae (Ammonoidea) from the middle reaches of the Volga River. Paleontological Journal 39, 629-644.

Mitta, V. 2009: The upper Bajocian - Lower Bathonian of Pechora River basin and Boreal-Tethyan correlation. Stratigraphy and Geological Correlation 17, 68-78. https://dx.doi.org/10.1134/s0869593809010067

Mitta, V.V. \& Alsen, P. 2013: Ammonites and zonal scale of the Bathonian of Greenland. In: Zaharov, V.A. et al. (eds): Jurassic System of Russia: Problems of Stratigraphy and Paleogeography. Fifth All-Russian Meeting, Tyumen, Russia, 23-27 September, 149-151.

Mitta, V., Zakharov, V.A., Barskov, I.S., Sel'tser, V.B. \& Ivanov, A.V. 2011: The Upper Bajocian-Lower Bathonian boundary section in the outskirts of Saratov: molluscan characteristics and biostratigraphy. Stratigraphy and Geological Correlation 19, 502-514. https://dx.doi. org/10.1134/s086959381105008x

Mitta, V., et al. 2015: Biostratigraphy and sedimentray settings of the Bajocian-Bathonian beds of the Izhmae River basin (European North of Russia). Neues Jahrbuch für Geologie und Palöntologie Abhandlungen 277, 307-335. https://dx.doi.org/10.1127/njgpa/2015/0507.

Mönnig, E. \& Dietl, G. 2017: The systematics of the ammonite genus Kepplerites (upper Bathonian and basal Callovian, Middle Jurassic) and the proposed basal boundary stratotype (GSSP) of the Callovian Stage. Neues Jahrbuch für Geologie und Paläontologie, Abhandlungen 286, 235-287. https://dx.doi.org/10.1127/njgpa/2017/0697

Mørk, A. et al. 1999: Mesozoic lithostratigraphy. In: Dallmann, W.K. (ed.): Lithostratigraphic Lexicon of Svalbard, Upper Palaeozoic to Quarternary bedrock. Review and recommendations for nomenclature use,
127-214. Committee on the Stratigraphy of Svalbard. Tromsø: Norwegian Polar Institute.

Müller, R.D. et al. 2016: Ocean basin evolution and global-scale reorganization events since Pangea breakup. Annual Review of Earth and Planetary Science Letters 44, 107-138. https://dx.doi.org/10.1146/ annurev-earth-060115-012211

Newton, E.T. \& Teall, J.J.H. 1897: Notes on a collection of rocks and fossils from Franz Josef Land, made by the JacksonHarmsworth Expedition during 1894-1896. The Quarterly Journal of the Geological Society of London 53, 477-518, pl. XXXVII-XLI. https://dx.doi.org/10.1144/gsl. jgs.1897.053.01-04.38

Nygaard, T.S. 2003: Biostratigraphical investigation of Middle Jurassic to uppermost Lower Cretaceous Albian) ammonites from East Peary Land and Kronprins Christian Land, eastern North Greenland. With some emphasis on the relation to the ammonite stratigraphy of the Svalbard archipelago. Unpublished Master's thesis, University of Copenhagen.

Olaussen, S., Dalland, A., Gloppen, T.G. \& Johannessen, E. 1984: Depositional environment and diagenesis of Jurassic reservoir sandstones in the eastern part of Troms I area. In: Spencer, A.M. (ed.): Petroleum Geology of the North European Margin, 61-79. London: Springer.

Page, K.N. 1989: A stratigraphical revision for the English Lower Callovian. Proceedings of the Geologists' Association 100, 363-382. https:// dx.doi.org/10.1016/s0016-7878(89)80055-0

Pedersen, S.A.S. 1991: Geological map of Kilen, Kronprins Christian Land, North Greenland, 1:100 000 (unpublished): In the archives of the Geological Survey of Denmark and Greenland (GEUS): http://data. geus.dk/geusmapmore/get_binary_mapdb.jsp?digitalmap_id=4313 (accessed: February 2012)

Pedersen, G.K., et al. 2018: Burial history of a folded Cretaceous succession - a case study from the southern part of Kilen, eastern North Greenland. Cretaceous Research 89, 22-35. https://dx.doi. org/10.1016/j.cretres.2018.03.007

Piasecki, S., Callomon, J.H. \& Stemmerik, L. 2004: Jurassic dinoflagellate cyst stratigraphy of Store Koldewey, North-East Greenland. Geological Survey of Denmark and Greenland Bulletin 5, 99-112. https://dx. doi.org/10.34194/geusb.v5.4810

Poulton, T.P. 1987: Zonation and correlation of middle Boreal to lower Callovian (Jurassic) ammonites, Salmon Cache canyon, Porcupine River, northern Yukon. Geological Survey of Canada 358, 155 pp. https://dx.doi.org/10.4095/122457

Quenstedt, F.A. 1886-1887: Die Ammoniten des Schwäbischen Jura: Der Braune Jura 2, 441-815. Stuttgart: Schweizerbart.

Ravn, J.P.J. 1911: On Jurassic and Cretaceous fossils from North-East Greenland. Meddelelser om Grønland 45, 437-500. https://dx.doi. org/10.5962/bhl.title.29066

Rawson, P.F. 1982: New Arctocephalitinae (Ammonoidea) from the Middle Jurassic of Kong Karls Land, Svalbard. Geological Magazine 119, 95-100. https://dx.doi.org/10.1017/s0016756800025693

Sokolov, D.N. 1912: Zur Ammonitenfauna des Petschoraschen Jura. Memoires du comité geologique de Saint-Pétersbourg 76, 1-49 (in Russian).

Stemmerik, L., et al. 1998: Wandel Sea Basin, eastern North Greenland. Geology of Greenland Survey Bulletin 180, 55-62. https://dx.doi. org/10.34194/ggub.v180.5086

Surlyk, F. 2003: The Jurassic of East Greenland: a sedimentary record of thermal subsidence, onset and culmination of rifting. Geological Survey of Denmark and Greenland Bulletin 1, 657-722. https://dx.doi. org/10.34194/geusb.v1.4674

Surlyk, F. et al. (in press): Jurassic stratigraphy of East Greenland. Geological Survey of Denmark and Greenland Bulletin $\mathbf{4 6}$

Svennevig, K. 2018: Geological map of Greenland, 1:100 000, Kilen 81 $\varnothing .1$ Syd, Geological Survey of Denmark and Greenland Map. Copenhagen: Geological Survey of Denmark and Greenland.

Svennevig, K., Guarnieri, P. \& Stemmerik, L. 2015: From oblique photogrammetry to a 3D model - structural modeling of Kilen, eastern North Greenland. Computers and Geosciences 83, 120-126. https:// dx.doi.org/10.1016/j.cageo.2015.07.008

Svennevig, K., Guarnieri, P. \& Stemmerik, L. 2016: Tectonic inversion in the Wandel Sea Basin: a new structural model of Kilen (eastern North Greenland). Tectonics 35, 2896-2917. https://dx.doi. org/10.1002/2016TC004152 
Svennevig, K., Guarnieri, P. \& Stemmerik, L. 2017: 3D restoration of a Cretaceous rift basin in Kilen, eastern North Greenland. Norwegian Journal of Geology 97, 21-32. https://dx.doi.org/10.17850/njg97-1-02

Svennevig, K., et al. 2018: Descriptive text to the Geological map of Greenland, 1:100 000, Kilen $81 \varnothing .1$ Syd. Geological Survey of Denmark and Greenland Map Series 8, 29 pp. + map. https://dx.doi.org/10.34194/ geusm.v8.4526

Tintant (H.), 1963: Les Kosmocératidés du Callovien inférieur et moyen d'Europe occidentale. Essai de paléontologie quantitative. Publications de I'Université de Dijon, t. 29, 1-500. https://gallica.bnf.fr/ ark:/12148/bpt6k4807624c/f11.item.textelmage.zoom
Voronets, N.S. 1962: Stratigraphy and cephalopod molluscs of the Jurassic and Lower Cretaceous deposits of the Lena-Anabar region. Trudy Nauchno-Issledovetel'skogo Instituta Geologii Arktiki 110, 237 pp. (in Russian)

Vosgerau, H., et al. 2004: Jurassic syn-rift sedimentation on a seawards-tilted fault block, Traill $\varnothing$, North-East Greenland. Geological Survey of Denmark and Greenland Bulletin 5, 9-18. https://dx.doi. org/10.34194/geusb.v5.4800

Whitfield, R.P. 1906: Notes on some Jurassic fossils from Franz Josef Land, brought back by a member of the Ziegler Exploring Expedition. Bulletin of the American Museum of Natural History 22, 131-134. 